\title{
As Possibilidades de uma Leitura do Fenômeno Jurídico a partir da Religião: a proposta metodológica e o exemplo da teologia política de João Calvino
}

\author{
The Possibilities of a Reading of the Legal Phenomenon From Religion: \\ the methodological proposal and the example of the political theology of \\ John Calvin
}

Caetano Dias Corrêa

Universidade Federal de Santa Catarina, Florianópolis - SC, Brasil

\begin{abstract}
Resumo: O presente trabalho discute e tenta lançar bases para uma abordagem do fenômeno jurídico a partir de um cabedal teórico próprio do estudo das religiões, diante das diversas e, muitas vezes, pouco exploradas interfaces entre direito e religião. Nesse sentido, apresenta-se os marcos teóricos para a empreitada proposta, os quais se valem da especificidade das categorias desenvolvidas no seio da ciência das religiões, tomando o fenômeno religioso por seus próprios aspectos religiosos e específicos, usando, em seguida, a teologia política de João Calvino como exemplo inicial de análise.
\end{abstract}

Palavras-chave: Religiões. Teologia. Direito. Sagrado. Calvino.
Abstract: This paper aims to discuss and try to lay the foundations for an approach to legal phenomenon from a theoretical leather study own religions, given the diverse, and often unexplored, interfaces between law and religion. In this sense, it presents the theoretical frameworks for the proposed approach, which is worth the specificity of the categories developed within the science of religions, taking the religious phenomenon by their own religious and specific aspects, using then John Calvin's political theology as initial sample analysis.

Keywords: Religion. Theology. Law. Sacred. Calvin.

Recebido em: 26/01/2017

Revisado em: 21/03/2017

Aprovado em: 28/03/2017 


\section{Introdução: proposta metodológica}

O intuito do presente trabalho não é propor uma análise do fenômeno religioso através de lentes jurídicas, mas justamente o oposto. Consiste em discutir e tentar lançar bases para uma abordagem do fenômeno jurídico a partir de um cabedal teórico próprio do estudo das religiões, diante das diversas, e muitas vezes pouco exploradas, interfaces entre direito e religião. Nesse sentido é imprescindível que o fenômeno religioso seja muito bem compreendido pelo pesquisador, em sua linguagem, suas categorias, seus processos e suas estruturas. Assim, o trabalho fundamenta-se em noções advindas não da reflexão jurídica propriamente dita, mas sim diretamente no contributo ao conhecimento trazido pela chamada ciência das religiões ${ }^{1}$, com contornos precipuamente antropológicos e complementos de cunho sociológico.

Por certo, o componente histórico também será de enorme importância para um estudo do jurídico a partir do religioso. Contudo, também será aqui enxergado a partir da compreensão advinda do estudo da religião por suas próprias especificidades. É que, por conta da inafastável interface entre o racional e o irracional, o celeste e o terrenal, faz-se necessário não analisar o fenômeno religioso como um objeto distante, estático, um edifício capaz de ter suas estruturas suficientemente decodificadas por um observador imparcial externo. Antes, é necessário imergir violentamente no âmbito do religioso.

\footnotetext{
${ }^{1}$ A Ciência das Religiões fundamenta-se na investigação sistemática da história das religiões, segundo seu desenvolvimento externo e suas características essenciais internas. A história das religiões deve não só esboçar a evolução externa e apresentar suas práticas e ideias fundamentais, mas também tornar visível seu lado inteiro, a saber, a fé que nelas se expressa e determina a piedade de indivíduos e dos portadores em sua totalidade (SMITH, 1979) [...] O objetivo da Ciência das Religiões é inventariar, de forma abrangente, os fatos do mundo religioso investigando suas inter-relações com outras áreas da vida, a partir de um estudo de fenômenos religiosos concretos. A Ciência das Religiões tem uma estrutura multidisciplinar. Trata-se de um campo de intersecção de várias subciências e ciências auxiliares. As mais referidas são: a História da Religião, a Sociologia da Religião e a Psicologia da Religião. Em Coelho (2009-2010). Ainda, para uma compreensão metodológica da ciência das religiões, conferir: Greschat (2005).
} 
A compreensão do fenômeno, que muitas vezes se apresenta em franco dualismo com o que é chamado secular, não prescinde da análise das experiências religiosas em seus elementos mais próprios e característicos, considerando-os em toda sua complexidade, levando em conta tanto suas categorias discursivas e classificações teológicas, quanto seus expedientes míticos, esotéricos, irracionais e desprovidos de sentido lógico, considerando-os como possíveis e reais.

Não se pretende, contudo, defender, seja cientificamente, seja com argumentos, a veracidade dos credos. Trata-se, precisamente, de considerar o fenômeno religioso sem o costumeiro desdém, ressaltando suas contribuições, como um dos elementos determinantes, à própria experiência antropológica, histórica e sociológica humana. Por isso, o presente trabalho analisa a reflexão de autores que, imbuídos da noção já descrita, foram competentes em apresentar o fenômeno religioso em termos e padrões interpretativos capazes de ressaltar toda sua importância, com o intuito de, ao empreender tal análise, fixar as bases iniciais para a compreensão da interface entre direito e religião, tomando, por exemplo, inicial a experiência estabelecida pela reflexão de João Calvino, com os desdobramentos teológico-políticos daí advindos.

\section{O Início da Abordagem do Fenômeno Religioso por sua Pró- pria Especificidade: Rudolf Otto ${ }^{2}$}

O primeiro autor analisado e evocado para a elaboração e o desenvolvimento da tese ora apresentada é Rudolf Otto, por sua abordagem pioneira a respeito do fenômeno religioso. Em obra antológica para o estudo das religiões, de 1917, intitulada "O Sagrado", o autor propõe um

2 Rudolf Otto (1869-1937), teólogo cristão alemão e estudioso da história e da fenomenologia das religiões. Rudolf Otto foi uma das grandes influências teológicas na Alemanha nos anos após a Primeira Guerra Mundial, sendo a outra o teólogo neoortodoxo Karl Barth. [...]. Enquanto Barth rejeitou a ênfase liberal no cristianismo como uma religião, Otto centrou o seu trabalho de vida em compreender a natureza da religião, suas expressões divergentes das religiões do mundo, e sua importância para a teologia e prática cristã. Biografia disponível em: <http://home.zonnet.nl/rudolfotto/Eliade Ludwig.html>. Acesso em: 15 nov. 2014. 
verdadeiro ponto de mutação dos padrões até então evidenciados na ciência das religiões.

É que, como asseverou Mircea Eliade (1992), em vez de se debruçar sobre conceitos, tais como Deus e religião, Otto dirigiu-se para um estudo aprofundado das modalidades da experiência religiosa. Dotado de um intelecto com grande refinamento psicológico e fortalecido por sua formação acadêmica em teologia e história das religiões, Rudolf Otto conseguiu esclarecer o conteúdo e o caráter específico dessa experiência.

A despeito do lado racional e especulativo da religião, prestigiou, sobretudo, a faceta irracional do fenômeno religioso. A partir da noção de "Deus vivo" de Lutero, havia compreendido o que essa noção queria significar para o crente. Para além de um Deus meramente conceitual, como para os filósofos, não era uma ideia, uma noção abstrata, uma simples alegoria moral. Era, pelo contrário, um poder terrível, manifestado na "cólera" divina.

Otto (1980) procurou, em sua reflexão, enfatizar os aspectos sensitivos, emocionais da experiência religiosa, em oposição a um estudo frio e meramente sistemático das categorias teológicas que cada religião encerrava, o que era até então a tônica da ciência das religiões. Ele buscou destacar a condição humana perante o sagrado, a enorme distância e diferença, que levava, por sua vez, ao medo, à devoção, ao sentimento de nulidade do homem perante o que chamou de misterium tremendum.

Utilizando-se do conceito de numinoso (do latim numen, que significa Deus), Otto (1980) descreve-o como experiência de manifestação radical e totalmente diferente, dissociada da apreensão racional dos conceitos teológicos. Para o autor, definir a experiência religiosa por meio de conceitos claros e acessíveis ao pensamento seria designar o racional como essência da divindade, o que, todavia, não se revelaria acertado, pois, embora os conceitos teológicos (tais como espírito, razão, vontade, onipotência entre outros) possam ser essenciais, acabam por esgotar de maneira muito rasa a essência da ideia de divindade. Entretanto, a compreensão dessa ideia não prescindiria da consideração daquilo que é irracional. Os conceitos seriam 
[...] sem dúvida, predicados essenciais, mas predicados essenciais sintéticos e unicamente serão compreendidos corretamente se tomados dessa maneira; isto é, como predicados atribuídos a um objeto que os recebe e sustenta, mas que não é compreendido por eles nem pode sê-lo, pois, ao contrário, há de ser compreendido de outra maneira distinta e peculiar. Pois de alguma maneira há de ser compreendido. (OTTO, 1980, p. 11)

Essa outra maneira de compreender o fenômeno, para Otto (1980), seria abrir os olhos para a emoção religiosa, a qual atuaria nas suas manifestações mais primitivas, pois a compreensão da religião não se reduziria a esquadrinhar o sistema de crenças a partir de enunciados racionais. O teórico resgata e destaca a noção de pavor diante do mistério, como traço característico da religião. O numinoso não pode ser entendido, tampouco explicado. Pode apenas ser sentido na experiência.

Mais uma vez comentando Otto, Eliade (1992) sustenta que o autor defenderia que, por se manifestar como uma realidade sempre diferente das demais realidades "naturais", o sagrado, em sua faceta irracional, tremenda, terrível, como símbolo sensitivo da experiência do homem com a divindade, a qual revela toda a infinita superioridade de Deus perante a infinita inferioridade do homem, seria o traço distintivo das religiões e, por isso, também o traço distintivo do estudo das religiões.

Em que pese estar ainda a depender da linguagem, mesmo que diante de todas as suas insuficiências e impossibilidades, para Rudolf Otto, não era senão por esse elemento radical que se poderia chegar à compreensão de um fenômeno que, por mais que possa vir a ser classificado e teorizado a partir de conceitos, jamais poderia ser afastado das noções inexplicáveis advindas da noção de fé, igualmente central no discurso religioso.

Em outras palavras, a reflexão de Rudolf Otto dirigia-se muito mais à crença e a seus elementos, do que à explicação teorizada dessa crença. Compreendê-la, se é que isso era possível, somente a partir da verificação da experiência traumática com o numinoso. Essa era sua ideia de sagrado. Esse era seu foco de estudo, o qual, todavia, acabava por menosprezar os 
esforços teóricos de sistematização conceitual das diversas religiões, sobretudo daquelas mais desenvolvidas neste aspecto, como o cristianismo.

O sagrado, o numinoso, como elemento definidor do objeto de estudo da ciência da religião, seria capturado pelo crente a partir de experiências radicais de aproximação entre divindade e homem, as quais deixariam marcas indeléveis nas vidas das criaturas, nulificadas perante a grandeza e a majestade do criador.

No que tange especificamente ao objeto de estudo desta pesquisa, é interessante notar que o autor também detectou tal característica na obra de Lutero. Com efeito, Otto assinala diversas passagens dos escritos do reformador em que o irracional, o incompreensível, o insondável, enfim, o mistério, é evocado como definidor da experiência religiosa. Segundo o Otto (1980, p. 140):

Uma vez que o sentimento numinoso é uma unidade, é de se esperar que, uma vez desperto, em qualquer de seus aspectos ou manifestações, se apresentem também todos os demais. Com efeito, todos eles se encontram de fato em Lutero, e desde logo no que eu chamaria de seus pensamentos à maneira de Jó. Vimos antes que no livro de Jó se trata menos da majestade tremenda do numen, do que da majestade misteriosa; isto é, do elemento irracional em sentido estrito, do mirum, do incompreensível e paradoxal, do oposto ao racional e à maneira racional [...]. Esta é a origem dos violentos impropérios de Lutero contra a "razão prostituta", que tem que parecer grotescos aqueles que não entenderam o problema do irracional no conceito de Deus.

Otto destaca em sua reflexão que Lutero sempre trará à tona em seus escritos as noções segundo as quais os caminhos de Deus são mais elevados que os dos homens, bem como que a fé se justificaria precipuamente frente ao caráter recôndito e insondável de Deus. Ressalta, ainda, que, a partir dessa tônica, estariam lançadas as bases para a teoria da predestinação, exposta em sua obra Nascido Escravo (que será posteriormente também desenvolvida por Calvino), em oposição à ideia de livre arbítrio, pois, como os desígnios de Deus não são acessíveis ao homem, não haveria como interferir em sua vontade. 
Enfim, é importante destacar que a reflexão de Otto revela-se importante porque lança um olhar até então inédito ao fenômeno religioso, olhar esse que teve o condão de evidenciar aspectos até então insondados pela ciência das religiões e que, a partir de tal obra, redefiniram as maneiras de analisar e compreender esse objeto. Sem dúvida, sua abordagem permanece a nortear aqueles que se aventuram a entendê-lo e explicá-lo.

Contudo, Mircea Eliade (1992), de maneira não menos perspicaz, revela, tempos depois, as limitações da reflexão de Otto. Na opinião do mestre romeno, não se deve analisar o fenômeno religioso apenas a partir das relações entre o racional e o irracional. Eliade (1992) entendia que a religião deve ser entendida em toda sua complexidade, e não apenas a partir de um embate dialético a partir de conceitos dicotômicos. Assim, se propôs a analisar o sagrado em sua totalidade, e não apenas naquilo que ele comportaria de misterioso.

\section{O Sagrado e o Profano: o conceito de Hierofania de Mircea Eliade $^{3}$}

Propondo a suplantação da já vanguardista noção de Otto, Eliade entende que o sagrado não se posiciona na dicotomia entre racional e irracional, mas sim na oposição àquilo que é considerado profano. Em outras

\footnotetext{
${ }^{3}$ Mircea Eliade (1907-1986), escritor e historiador romeno nascido em Bucareste, Romênia, considerado o mais importante e influente especialista em história e filosofia das religiões. Ficou conhecido pelas pesquisas que empreendeu sobre a linguagem simbólica das diversas tradições religiosas. [...] Formou-se em filosofia pela Universidade de Bucareste (1928). [...] De volta à Romênia (1932), doutorou-se no departamento de filosofia [...] (1933) [...]. Após a Segunda Guerra Mundial (1945) [...] por suas convicções direitistas não voltou para a recém Romênia comunista e estabeleceu-se em Paris. Tornou-se professor de religião comparativa na École des Hautes Études, na Sorbonne [...]. Emigrando para os EUA, estabeleceu-se definitivamente em Chicago, onde passou a lecionar história das religiões na Universidade de Chicago (1956). Passou a chefiar o Departamento de Religião da Universidade de Chicago (1958), cargo que ocupou até à sua morte [...]. Entre suas principais obras, caracterizadas pela interpretação das culturas religiosas e a análise das experiências místicas, foram Traité d'histoire des religions (1949) e Le Sacré et le profane (1965). Biografia disponível em: <http://www.dec.ufcg.edu.br/biografias/MirceaEl.html>. Acesso em: 20 ago. 2015.
} 
palavras a compreensão do fenômeno religioso se daria a partir da dicotomia entre o sagrado e o profano.

O estudo das manifestações do sagrado ao longo dos tempos revela não somente representações simbólicas, ícones religiosos, ou mesmo diferentes abordagens analíticas a respeito de tais manifestações (isto é, diferentes teologias), mas também possibilita conhecer os diferentes modos de interação do homem para com o sagrado a partir de suas próprias circunstâncias históricas, revelando e evidenciando as influências dos meios materiais nas práticas religiosas, seja no âmbito epistemológico, filosófico ou mesmo econômico e social, assim como as reminiscências transcendentais no modus vivendi secularizado.

Dito de outra forma, é preciso empreender à própria dialética do sagrado como representação divina que se opõe ao profano. Por sua vez, o conceito de profano aqui é entendido como tudo aquilo tachado de natural e secularizado pelo homem religioso. Segundo Eliade (1992, p. 17), "[...] o homem toma conhecimento do sagrado porque este se manifesta, se mostra como algo absolutamente diferente do profano". Da mesma forma, “[...] todas as definições do fenômeno religioso apresentadas até hoje mostram uma característica comum: à sua maneira, cada uma delas opõe o sagrado e a vida religiosa ao profano e à vida secular" (ELIADE, 1992, p. 20). Esse é o mote inicial da reflexão de Eliade. Para desenvolvê-la, fará uso de um conceito fundamental em sua obra: o de hierofania.

A hierofania, como aparecimento ou manifestação reveladora do sagrado, é a conotação desenvolvida por Mircea Eliade em seu Tratado de História das Religiões e posteriormente retomada em $O$ sagrado e o Profano: a Essência das Religiões. As hierofanias se revelam como verdadeiros documentos históricos, pois exprimem, ao seu modo, uma categoria do sagrado e um momento da sua história, revelando tanto a própria manifestação do sagrado quanto uma situação do homem em relação a este sagrado. Isto porque o sagrado sempre se manifesta inserido em um contexto histórico. Até mesmo as experiências místicas mais individuais e transcendentes sofrem a influência do momento histórico (ELIADE, 1992). 
Por isso, é necessário também compreender o lugar do sagrado no pensamento religioso, bem como sua relação com as estruturas milenares consolidadas no panorama de sua própria religião. É importante verificar quais as relações estabelecidas entre as estruturas religiosas, quais suas aproximações e distanciamentos, bem como os modos de lidar com as manifestações do sagrado e de significá-las no cotidiano. Isso porque, como também afirma Eliade (2002), a história das religiões é em grande parte a história das desvalorizações e das revalorizações das hierofanias, pois, para aquele que se acreditava de posse de uma nova revelação, as antigas hierofanias não somente perdem o seu valor, mas também passam a ser percebidas como obstáculos a uma experiência religiosa genuína.

Enfim, o que autor buscava, “[...] acima de tudo, é apresentar as dimensões específicas da experiência religiosa, salientar suas diferenças com a experiência profana do Mundo" (ELIADE, 1992, p. 22). Assim, fossem racionais ou irracionais, as manifestações do sagrado deveriam ser objeto de análise, pois a oposição passa a ser não mais com as categorias e objetos de análise do fenômeno religioso, como em Otto, mas sim entre o fenômeno religioso considerado em sua totalidade complexa, e o aspecto profano da vida.

A experiência religiosa, portanto, seria a experiência do sagrado em oposição ao profano. Para Eliade (1992), a história das religiões - desde as mais primitivas às mais elaboradas - é constituída por um número considerável de hierofanias, pelas manifestações das realidades sagradas.

Nada obstante, de acordo com o pensamento do autor, seria possível falar, ainda, por meio da hierofania, da própria sacralização do profano. Desde a mais elementar hierofania - por exemplo, a manifestação do sagrado num objeto qualquer, uma pedra ou uma árvore, e até a hierofania suprema, que é, para um cristão, a encarnação de Deus em Jesus Cristo, estar-se-ia '[...] diante do mesmo ato misterioso: a manifestação de 'algo de ordem diferente' - de uma realidade que não pertence ao nosso mundo - em objetos que fazem parte integrante do nosso mundo 'natural', 'profano"” (ELIADE, 1992, p. 135). 
Enfim, a manifestação do sagrado se daria, também, pela apropriação de elementos, objetos, estruturas até então profanas, mediante a sua separação e seu destaque a partir da atribuição de significações do sagrado.

As formas e os meios de manifestação do sagrado variam de um povo para outro, de uma civilização para outra. Mas resta sempre o facto paradoxal - isto é, ininteligível - que o sagrado se manifesta e, por conseguinte, se limita e cessa assim de ser absoluto. Isto é muito importante para a compreensão da especificidade da experiência religiosa se admitirmos que todas as manifestações do sagrado se equivalem, que a mais humilde hierofania e a mais terrível teofania apresentam a mesma estrutura e se explicam pela mesma dialética do sagrado, compreenderemos então que não existe uma ruptura essencial na vida religiosa da humanidade. Examinemos de mais perto um só exemplo: a hierofania que teve lugar numa pedra e a teofania da Encarnação. O grande mistério consiste no próprio facto de o sagrado se manifestar, porque, como já vimos atrás, ao manifestar-se, o sagrado limita-se e "historiciza-se". Percebemos a que ponto se limita o sagrado, ao manifestar-se numa pedra. Mas estamos inclinados a esquecer de que o próprio Deus aceita limitar-se e historicizar-se, encarnando em Jesus Cristo. Isto é, repetimo-lo, o grande mistério, o misterium tremendum; o facto de o sagrado aceitar limitar-se. [...] Bem entendido, existem grandes diferenças entre as inúmeras hierofanias, mas nunca se deve perder de vista que as suas estruturas e a sua dialética são sempre as mesmas. (ELIADE, 2000, p. 137)

Ou seja, Eliade (2000) propõe, com seu conceito de hierofania, uma categoria basilar para a compreensão de todo o fenômeno religioso. O sagrado se manifesta e, ao se manifestar, o faz estabelecendo uma dicotomia com relação ao que está excluído de seu espectro, delimitando-o como profano e, assim, estabelecendo fronteiras a separar tempo, espaço e lugares, territórios, objetos, processos e estruturas, definindo onde começa e termina a experiência religiosa.

Cada tipo de hierofania, entendida esta como a irrupção do sagrado, cada uma ao seu modo, permite uma dada e diferente aproximação 
do sagrado. A hierofania, com poucas exceções, é um epifenômeno que se apresenta a um indivíduo e constitui nele uma experiência fundante ou transformadora, ou mesmo mantenedora de uma forma de religião. No primeiro caso, temos os indivíduos fundadores de religiões; no segundo, os profetas que pregam a volta às origens da religião instituída ou a correção de seus desvios e, por último, o reforço do sagrado dominado, cujos exemplos melhores são as aparições da Virgem que estabelecem romarias a locais sagrados. Neste último caso, a "aparição" do sagrado que se revela em um de seus aspectos, mas que traz em si, por definição, a totalidade do seu ser (no caso da Virgem que se revela por inteira), a religião instituída apressa-se em limitar ou especializar seu poder de modo a dominá-lo. Toda limitação (regulamentação) da aparição ou epifenômeno significa colocá-lo sob custódia. (MENDONÇA, 2002, p. 32)

Entretanto, a manifestação do sagrado se dá, ao mesmo tempo, pela apropriação de algo que até então era considerado profano, indistinto dos demais elementos do mundo. Uma hierofania pode se apropriar de uma pedra, uma árvore, um animal etc.

De qualquer forma, o sagrado se manifesta e se localiza no tempo e no espaço, adquirindo significação histórica, limitando-se, em contraposição à noção de sua própria onipotência, ao seu caráter absoluto. Por meio da hierofania, o sagrado, de total, passa a ser limitado, recortado, enquadrado, emoldurado.

Dessa apropriação, no pensamento de Eliade, surgem os mitos, as imagens, os símbolos, os quais pertencem à substância da vida espiritual. "Eles podem ser camuflados, mutilados, degradados, mas jamais extirpados" (ELIADE, 1991). Símbolos, imagens e mitos estão presentes em todos os momentos da experiência do sagrado.

Com a Reforma Protestante, por exemplo, o cristianismo revelou novas hierofanias e, com isso, novas imagens, símbolos e mitos. Assim como a encarnação do Verbo Divino, os milagres de Cristo, o Dia de Pentecostes, as visões do Apocalipse de João, entre outros muitos fatos narrados no Novo Testamento e na história da igreja cristã, os eventos que caracterizam a contestação da autoridade eclesial romana, situados nos 
séculos XV e XVI, encabeçados por Martinho Lutero, João Huss, Ulrich Zwinglio, Guilherme Farel e João Calvino, entre outros, sem dúvida, trazem à tona novos expedientes de manifestação do sagrado no interior do cristianismo (considerado religião), os quais, não obstante significarem uma ruptura para com a teologia católica, demonstraram grande poder e influência no seio da sociedade europeia a partir do início da modernidade.

Tais hierofanias, entretanto, guardavam uma peculiaridade: sua intelectualidade. As manifestações do sagrado evidenciadas no seio da Reforma constituíam-se em representações discursivas teológicas surgidas a partir de reflexões intelectuais, baseadas, sobretudo, na redescoberta e na releitura do próprio texto bíblico, marginalizado pela liturgia medieval católica. Ou seja, novos mitos, novas imagens e novos símbolos.

Em que pese estarem impregnadas de elementos místicos, inerentes à própria dialética do sagrado como representação divina que se opõe ao profano, as hierofanias da Reforma apresentam uma nova legenda para o relacionamento entre o cristão e seu Deus, uma nova representatividade da aliança selada entre Cristo e sua igreja, o que será visto nos capítulos posteriores.

Contudo, para os fins perseguidos por esta pesquisa, a reflexão de Mircea Eliade, assim como a de Rudolf Otto, também não se se afigura suficiente. Em que pese a clareza de sua exposição, bem como a pertinência dos critérios e abordagens empreendidos, a compreensão das decorrências jurídicas tomando como partida o prisma do fenômeno religioso demanda um pano de fundo teórico que, conglobando as descobertas de Otto e de Eliade, apresente também os alicerces de uma experiência que admita um elemento regulador, ordenador, o qual, por sua vez, dará lugar a uma abordagem acerca da juridicidade em face da religião.

Partindo-se do exame do lado irracional da religião por Otto e passando-se pelas hierofanias de Eliade, com sua consideração do sagrado em sua totalidade e oposição ao profano, chega-se, a posteriori, numa espécie de síntese, ao sagrado selvagem de Roger Bastide, conceito que, conjugado com os demais, conferirá as bases teóricas iniciais para a tentativa de compreensão do fenômeno jurídico a partir de categorias do pensamento e da experiência relogiosa. 


\section{O Sagrado Selvagem na Visão de Roger Bastide ${ }^{4}$}

A hierofania de Eliade apresenta ao campo teórico da ciência das religiões a ideia de manifestação do sagrado. O inefável, absoluto e insondável se apropriou de um elemento profano e se fez inteligível, identificável, limitado, situado, datado. No entanto, tal reflexão não tece maiores considerações sobre a dinâmica das formas de manifestação do sagrado. Estabelece a categoria basilar de análise do fenômeno religioso, o que, sem dúvida, é muito importante para a compreensão do fenômeno, mas não descreve a dialética por meio da qual o sagrado se manifesta nas diversas hierofanias.

Por isso, em complementação a tal raciocínio, buscou-se o pensamento de Roger Bastide, o qual irá, em seus escritos, qualificar e descrever a tipologia da manifestação do sagrado, a partir do conceito de sagrado selvagem e de sua interação dialética com o sagrado domesticado (ou o sagrado instituinte e sua relação com o sagrado instituído).

Bastide (2006), em seu ensaio intitulado O Sagrado Selvagem, assim denomina o movimento de irrupção do sagrado, em um estado de efervescência, quando ele se manifesta em todo seu fervor, de maneira ilimitada e irresistível. Ao que parece, a ideia de Bastide acaba por qualificar o conceito de hierofania de Eliade, caracterizando-o como algo incontrolável, como uma manifestação fundante (ou refundante) e espontânea do sagrado sem parâmetros, limites ou amarras, que institui uma nova forma de interação (BASTIDE, 2006).

A reflexão de Antonio Gouveia Mendonça ${ }^{5}$, um dos principais comentaristas de tais conceitos no âmbito da academia brasileira, ajuda a

\footnotetext{
${ }^{4}$ Roger Bastide (1898-1974), sociólogo e antropólogo francês. Professor de filosofia na Universidade de São Paulo e da Sorbonne. Estudou os conflitos culturais e o problema da integração social nas populações brasileiras e as relações ideologia-religião. Biografia disponível em: <http://www.biografiasyvidas.com/biografia/b/bastide.htm>. Acesso em: 30 nov. 2014.

${ }^{5}$ Antonio Gouveia Mendonça (1922-2007), professor Emérito do Programa de Mestrado e Doutorado em Ciências da Religião da Universidade Metodista de São Paulo (UMESP). Professor do Programa de Pós-Graduação em Ciências da Religião da Universidade Presbiteriana Mackenzie - São Paulo.
} 
compreender o conceito. Mendonça (2002, p. 30), valendo-se inicialmente das lições de Eliade, assegura que

[...] a experiência do sagrado fundamenta-se num fenômeno, numa aparição. Ora, um fenômeno, ou uma 'aparição' como preferem os existencialistas, por si só, ou por definição, já é uma limitação do ser, não é todo o ser. O sagrado da experiência não se mostra por inteiro, pois que se isto ocorrer já não é mais um sagrado, não é um deus.

Prosseguindo, introduz a ideia de Bastide, para quem '[...] o homem é uma 'máquina de fazer deuses' que, à medida que o sagrado se torna 'frio' (froid) nas instituições religiosas (igrejas) recria o sagrado 'quente' (chaud), que ele chama de 'sagrado selvagem'. A irrupção do sagrado constitui um ponto de efervescência, un point d'orgue, isto é, uma suspensão na cadência musical (caldeirão)" (MENDONÇA, 2002, p. 32). Em outro ensaio, Mendonça (2002, p. 23) ainda irá dizer que:

O sagrado selvagem se erige como uma teoria antropológica e sociológica extremamente útil para a compreensão e explicação de toda dinâmica social da religião ao nos mostrar o mecanismo que faz desse extraordinário fenômeno humano a fonte principal emergente e subjacente da maior parte das coisas que acontecem na história. Bastide toma, como ponto de partida de seu instigante ensaio o movimento (a dinamis) latente em um sagrado difuso, presente nas formas arquetípicas da natureza humana (Jung) ou na história da humanidade (Eliade) e que se manifesta progressivamente na construção das instituições humanas, sejam religiosas ou políticas.

Por sua vez, Adailton Maciel Augusto (2010, p. 32), enxergando a aproximação do mestre à reflexão de Bastide, sedimenta que

[...] para Mendonça, foi Bastide, no 'Sagrado Selvagem' que definiu com clareza todo o processo dialético que há entre o sagrado não dominado (instituinte), o sujeito-objeto da experiência religiosa, e o sagrado dominado (instituído), da instituição religiosa. 
Com efeito, Bastide (2006) apresenta o sagrado selvagem a partir de um ponto de vista explosivo para, a partir dele, falar das experiências de institucionalização, delimitação, administração dessa experiência primeira irresistível.

Nietzsche, é verdade, proclamou a morte dos Deuses, esperando que Foucault proclamasse a morte do homem (o que é lógico, já que o homem só se constitui como homem através de sua relação com os Deuses). [...]

Mas será que a morte dos Deuses instituídos acarretaria o desaparecimento da experiência instituinte do Sagrado em busca de novas formas nas quais se encarnar? Será que a crise das organizações religiosas não adviria de uma não-adequação, cruelmente vivenciada, entre as exigências da experiência religiosa pessoal e os quadros institucionais nos quais quiseram moldá-la - com vistas, muitas vezes, a retirar-lhe o seu poder explosivo, considerado perigoso para a ordem social? (BASTIDE, 2006, p. 251)

Assim, em sua teoria, Bastide (2006, p. 257) expõe, como assinalou Augusto, o sagrado selvagem como experiência fundante, um chamado divino, ao qual se segue todo um esforço de domesticação, um esforço para submetê-lo ao controle da coletividade, "[...] com vistas a transformar o espontâneo em institucional”.

Prossegue o autor indicando que "[...] toda vez que o controle da comunidade relaxa, por um ou por outro motivo, tudo aquilo de selvageria latente que está contido no transe faz rebentar sua roupagem institucional." (BASTIDE, 2006, p. 257).

Por conta desse risco, “[...] a religião se desenvolve, a partir dessa incidência, como instituição de gestão da experiência do sagrado [...]" (BASTIDE, 2006, p. 263), a qual, em que pese permitir sua continuidade como comemoração e memória, aprisiona o sagrado selvagem, o sagrado instituinte "[...] atrás das grades dos seus dogmas ou da sua liturgia burocratizada [isto é, o sagrado instituído], de modo a que ele não mais desperte em inovações perigosas, em outro discurso que não o aceito pela ortodoxia.” (BASTIDE, 2006, p. 263). 
Toda igreja constituída possui decerto seus místicos, mas desconfia deles, delega-lhes seus confessores e diretores espirituais para dirigir, canalizar e controlar seus estados extáticos, isso quando não os trancafia em algum convento de onde seus gritos de amor desvairado não conseguem se fazer ouvir. (BASTIDE, 2006, p. 263)

\section{Porém,}

A sociedade vai mudando, porém, ao redor desse bloco que quer manter um passado enterrado. Daí os despertares, os movimentos por reformas, as heresias, os messianismos e os milenarismos, para tentar lutar contra a defasagem sempre crescente entre as infra-estruturas móveis e as superestruturas conservadoras. (BASTIDE, 2006, p. 263)

O sagrado instituído, pois, entra em crise, dando novas chances de irrupção do sagrado instituinte, o qual, porém, tenderá a ser novamente domesticado, instituído.

Tal é o nó do problema colocado pelo sagrado selvagem. A Bíblia nos propõe uma série de exemplos impressionantes dessas metamorfoses do sagrado selvagem em sagrado domesticado, como se o selvagem só pudesse sobreviver com a condição de domesticar-se. O encontro de Moisés com Deus no monte Sinai, em meio a tempestades e nuvens rasgadas por relâmpagos, prolonga-se com o aporte da Lei ao povo de Israel; a sarça ardente que queima no deserto, de mistério torna-se símbolo decifrável; a luta noturna de Jacó com o Anjo deixa a sua cicatriz indelével no corpo extenuado pelo combate... Vários inovadores, hoje em dia, tanto sociais como religiosos, percebem essa necessidade; eles precisam elaborar, a partir de suas experiências-piloto, outros modos de viver e adorar em conjunto: as festas coletivas arrefecem em liturgias repetidas, o fascinante do sagrado se traduz em planos de utopias, em reformas das Igrejas ou em contra-Igrejas luciferianas. (BASTIDE, 2006, p. 273)

Mais uma vez comentando o pensamento de Bastide, Mendonça (2010, p. 477) assinala que "[...] o sagrado fica cada vez mais distanciado 
na medida em que os especialistas aperfeiçoam um discurso escrito e oral 'sobre' o sagrado". Prossegue o autor dizendo que

[...] o vácuo que se abre entre o crente e o sagrado aumenta na mesma proporção em que a instituição se burocratiza [...]. Nesse momento, um como que sentimento de orfandade por parte dos fiéis explode num movimento sectário de recuperação do sagrado em seu estado de pureza primitiva. (MENDONÇA 2010, p. 477)

Nesse permanente movimento de aprisionamento e liberação parcial do sagrado, numa seqüência dialética de afirmação e negação, pode-se depreender uma lei que rege o caminho da experiência religiosa (experiência do fenômeno do sagrado) à institucionalização da religião e vice-versa: quanto mais rígida e sujeita a doutrinas estabelecidas e consolidadas for uma instituição religiosa, mais sujeita estará a divisões ocasionadas pela necessidade de liberação do sagrado. (MENDONÇA, 2002, p. 32)

Enfim, a dialética do sagrado selvagem apresentada por Bastide, na senda das reflexões de Otto e Eliade, que o antecederam, auxilia a compreender o fenômeno religioso, sobretudo em seus fluxos e refluxos representados pelos movimentos de selvageria e institucionalização.

\section{O Fenômeno Jurídico sob o Prisma Religioso: o exemplo da teologia política de João Calvino}

A essa altura do desenvolvimento do presente texto é bem possível que já tenham surgido na mente do leitor as seguintes questões: mas o que essa reflexão sobre o objeto da ciência das religiões tem a ver com o direito? E com a teologia política de João Calvino ${ }^{6}$ ? E o que a Reforma, como hierofania, que passa do sagrado selvagem ao sagrado domesticado, tem a ver com o direito?

Com efeito, o exemplo da Reforma, sobretudo na experiência suíça, capitaneada por Calvino, ajuda a responder tais indagações. Calvino, no

${ }^{6}$ Para uma análise específica e mais completa da teologia política de Calvino, conferir: Corrêa (2015). 
vértice de um movimento de institucionalização do sagrado selvagem que foi a Reforma, viu-se impelido a construir um edifício teológico capaz de conter as irrupções de selvageria.

Passado o momento iconoclástico da ruptura com o catolicismo, foi necessário domesticar o sagrado não domesticado. Essa foi a empresa de Calvino em sua reflexão teológica. Todavia, como doutrinador de uma cidade que se organizava política e juridicamente a partir de conceito teológicos, Calvino acabou por teorizar também nessas áreas, vindo a falar da organização do governo civil e da ordenação da lei e do direito.

Ou seja, a reflexão jurídico-política de Calvino brota de seu esforço teológico de contenção do sagrado selvagem manifestado na hierofania da reforma. À irracionalidade do sagrado selvagem, Calvino opõe a racionalidade de sua instituição intelectual teológica. E tal reflexão estabilizadora, contudo, não deixa de ter seus efeitos jurídicos.

Mais uma vez, as ideias de Mendonça (2002, p. 32) ajudam a compreender essa relação teórica:

Há, no protestantismo, particularmente na tradição reformada propriamente dita, um paradoxo permanente: ao mesmo tempo em que sustenta forte rigidez dogmática, seja por determinadas formas de interpretação da Bíblia, seja pelas formulações simbólicas consagradas em confissões de fé, falta-lhe centros de autoridade que definam pontos de divergência. Como conseqüência, são freqüentes os expurgos de pessoas e grupos que, por seu lado, reiniciam processos de institucionalização que desembocam em novas igrejas. Quanto maior for a rigidez dogmática, maior será a possibilidade de divergências no interior da religião instituída, ou igreja. Quando falamos em religião instituída como aquela que atingiu o máximo em sua construção dogmática, temos de considerar que esta religião formou poderosa elite intelectual capaz não somente de sustentar seus símbolos, mas também de oferecer alternativas quando estes símbolos são contestados.

Quando a contestação se dá no campo intelectual, os contestadores são geralmente tolerados; no máximo são olhados com desconfiança 
pela ortodoxia e, vez por outra, sofrem pequenas advertências ou disciplinas. Nesse caso, as querelas ainda laboram no campo do sagrado dominado. Os problemas surgem com maior gravidade quando pessoas ou grupos insatisfeitos com a rotina eclesiástica, ou instigados por situações de efervescência social, decidem liberar o sagrado em favor de uma religião mais emocional que possa amenizar os impactos situacionais do cotidiano. As mudanças institucionais, regra geral, têm início, não por contestação intelectual, mas pela liberação ao menos parcial do sagrado por meio de formas emocionais de experiência religiosa:

A história mostra que, das tradições cristãs, a vertente mais sujeita a divisões é a calvinista, ou reformada propriamente dita, pela simples razão de que é a que mais produziu confissões ou símbolos de fé. No universo da Reforma, essa tendência caminha inversamente na medida em que documentos simbólicos escasseiam ou são ausentes. (MENDONÇA, 2002, p. 33)

Por isso, a conclusão segundo a qual o empreendimento que se pretendia purificador da Reforma, questionando e expurgando imagens, símbolos, ritos e mitos agregados ao cristianismo, acabou por questionar e fragilizar, por conseguinte, os mitos constitutivos do próprio cristianismo, do que se conclui que, no protestantismo reformado, o “[...] exílio do sagrado se deu em grau quase extremo” (MENDONÇA, 2010, p. 484).

É possível notar, assim, o quão próxima do objeto desta pesquisa está a reflexão teórica apresentada neste capítulo. Com efeito, as abordagens propostas por Otto, Eliade e Bastide favorecem a compreensão do panorama religioso da Reforma, bem como facilitam a identificação dos fins e objetivos que perseguia Calvino ao compor sua obra doutrinária, a qual produziu nítidos reflexos no mundo jurídico.

O sagrado, então preso (na opinião dos reformadores) na dogmática católica, irrompe selvagem na Reforma. Domá-lo novamente parece ser a tarefa dos teóricos e clérigos reformados. E essa doma não poderia vir senão a partir da edificação de um novo edifício teológico institucional. É necessário domesticar o sagrado selvagem, instituinte, transformando-o em instituído, mas agora sobre novas bases reformadas. 
É exatamente isso que Calvino fará. E o fará de uma forma que, representando a consolidação da ruptura com o modelo religioso eclesiástico romano estabelecido, em que pese ainda manter como válida grande parte do sistema teológico católico, acabará por significar, nesse momento criativo, a estipulação, ainda que incipiente, de novas perspectivas jurídicas, uma vez que, como assevera Höpfl (2005, p. XV),

[...] tamanha era a interpenetração entre o secular e o espiritual no século XVI, que nenhuma reforma da religião poderia ser feita sem uma transformação da ordem pública nas unidades políticas da Europa cristã, e nenhuma mudança nesse sentido poderia ser institucionalizada sem a assistência dos governantes seculares.

A despeito de toda sua formação intelectual e de todas as características de sua reflexão, o intento teológico de Calvino é, acima de tudo, estabelecer o tempo e o espaço para o exercício da verdadeira religião, a partir da supremacia da Sagrada Escritura. Ou seja, Calvino se ocupa em criar as condições para o perfeito exercício da fé cristã, o qual se daria tanto na vida pública quanto na vida privada.

E, para tal estabelecimento, necessário era ditar as regras para uma vida consagrada. Porém, na experiência histórica dessa concepção teológica de simbiose, os efeitos experimentados nos cidadãos-fiéis vêm sendo altamente questionados pelos estudiosos do tema. Johnson (2001), embora um autor de orientação católica e conservadora, assinala que, se, por um lado o luteranismo era basicamente conservador em sua doutrina, quase uma forma de catolicismo de Estado, privada de seus aspectos mecânicos, despojada e simplificada, mas não diferente, em essência, do cristianismo medieval, por outro, o calvinismo foi além, num experimento radical em teocracia, uma tentativa de reduzir o organismo medieval da Igreja-Estado a suas supostas origens primitivas. Para tanto, ergueu uma organização terrena que, com base em sua concepção teológica, precisava policiar a vida do fiel, para manter puros os predestinados e excluir da comunidade os fadados à danação.

O aspecto disciplinar da Igreja ganhava corpo, de modo que os clérigos eram imbuídos da missão de tomar conta da vida de cada um, em 
vistas de admoestar e corrigir os desvios, na concretização de uma sociedade cristã total, motivada pelo mesmo conceito agostiniano de criação da cidade de Deus na terra.

Höpfl (2005), ainda que de maneira menos veemente, também assinalará essa hipertrofia do poder de polícia da Igreja. Ele denota que, mesmo que tributário das convencionais distinções entre liberdade cristã e obediência civil, presentes já em Lutero, assim como as de justiça verdadeira e justiça exterior, governo espiritual e governo civil, Calvino não tardou em atribuir aos magistrados o policiamento da idolatria, do sacrilégio, da blasfêmia e de outras afrontas públicas à religião.

Calvino tinha plena consciência de que o estabelecimento e a manutenção da Igreja e, por conseguinte, da comunidade cristã no tempo e no espaço demandava mais do que a elaboração e a pregação de meros postulados éticos e morais cristãos. As punições e ameaças terrenais seriam indispensáveis, o que justificaria a instituição e o aparelhamento do poder civil para realizar o trabalho de Deus.

A magistratura deveria, pois, agir em prol da disciplina, mas sem condições de interferir na Igreja. Ao contrário, seria a Igreja quem atuaria como fiadora e salvaguarda do poder civil. Calvino virtualmente abandonou as tentativas de definir uma área específica de questões seculares, que estaria sob a jurisdição dos governantes seculares. É nesse momento que Höpfl (2005, p. XXIV) resume a teologia política de Calvino:

Pode-se apresentar um breve sumário da teologia política de Calvino, algo impossível com relação a Lutero. Só existe no universo um imperium, majestas, puissance, que se impõe com autoridade absoluta e incondicional: Deus. Toda autoridade legítima no mundo deriva direta ou indiretamente de Deus. À diferença de seus seguidores e dos teólogos e filósofos jesuítas muito mais sofisticados intelectualmente, que se opunham a eles e ao Direito Divino, Calvino não se interessou pela forma precisa por intermédio da qual essa autoridade derivada seria obtida. Ele se refere a ela como sendo "delegada", como "legação" (a autoridade de um legado), como sendo exercida por vice-gerentes, representantes (vicarii, vices) ou lugar-tentenes. Quando menciona a autoridade eclesiástica, empre- 
ga também as palavras "enviados" ou "embaixadores". Em todos os casos, porém, sua linguagem remete à metáfora da relação entre um imperador e seus subordinados, e o objetivo da metáfora é, sem dúvida, salientar a extrema condicionalidade da autoridade dos últimos em relação ao primeiro.

Mais uma vez diferentemente de Lutero, Calvino admite a ideia de governo cristão. Esse governo cristão se caracteriza por uma dupla direção, um duplo ministério de magistrados e pastores, ambos com autoridade derivada de Deus e ambos encarregados de comandar o mesmo conjunto de pessoas, de modo que a única relação possível entre eles é a da cooperação e restrição recíprocas, idealmente complementadas por alguma forma de restrição imposta aos dois pela comunidade dos fiéis cidadãos. Meta dessa cooperação é a construção (aedificatio, um termo do apóstolo Paulo) do reino de Deus no mundo (HÖPFL, 2005).

O povo, que deve ser dirigido rumo à salvação, necessitaria, para Calvino, de instrução e disciplina, esta última traduzida na ideia de restrição, de freio, de trava. Seria, portanto, necessário prescrever um código de conduta, com proibições e proscrições de determinados comportamentos, diante da inerente propensão da humanidade decaída à maldade, ao pecado e, por conseguinte, ao distanciamento de Deus. Paolo Prodi (2005, p. 270) descreve um pouco mais analiticamente essas interpenetrações:

Seguindo o mais ilustre exemplo, o das ordonnances ecclésiastiques da Igreja de Genebra, de 1561 (elaboração das precedentes de 1541), vemos que elas são promulgadas pelos prefeitos, pelo pequeno e pelo grande conselho da cidade: os pastores-ministros são escolhidos e nomeados pelo conselho citadino restrito e, ao iniciarem seu cargo, devem prestar um juramento solene perante os prefeitos e o próprio conselho: os visitadores são quatro, dois eleitos pelo conselho citadino e dois pelo conselho dos ministros pastores. No que concerne à disciplina, o ponto central é a presença, junto aos pastores, aos doutores-teólogos e aos diáconos, dos "anciãos" eleitos pelos vários conselhos citadinos e que formam como órgão colegiado o consistório: "seu ofício é cuidar da vida de cada um, admoestar gentilmente aqueles que percebem que incorrerão em erro e levarão uma vida desordenada. $\mathrm{E}$, nos casos em que o in- 
divíduo se mostra capaz, relatar à companhia, que será delegada a fazer correções fraternais e então exercê-las habitualmente com os outros". No entanto, a especificação de que o consistório não derrogue de modo algum a autoridade do governo citadino e da justiça ordinária é claramente fruto das tensões dos anos anteriores: confirma-se que o consistório pode ser presidido por um dos prefeitos, mas apenas na qualidade de ancião, sem a vara que é símbolo da autoridade secular, como era usual em tempos anteriores.

Will Durant (1957, p. 394), por sua vez, apresenta essa realidade de maneira ainda mais crua:

O ministério dividia-se em pastores, professores, irmãos leigos e diáconos. Os pastores de Genebra constituíam "A venerável companhia", que governava a Igreja e preparava os candidatos para o ministério. [...] O novo clero, conquanto não reivindicasse os milagrosos poderes dos sacerdotes católicos e decretasse sua própria inelegibilidade para os cargos civis, tornou-se, sob a sua direção de Calvino, mais poderoso que qualquer outros sacerdotes desde o tempo do antigo Israel. A verdadeira lei, em um Estado cristão, disse Calvino, deve ser a Bíblia; o clero é o justo intérprete dessa lei, estado a ela sujeitos os governos civis, os quais devem fazer com que seja cumprida, conforme é assim interpretada. Os homens práticos, naqueles conselhos, podiam ter tido suas dúvidas sobre esses pontos, mas achavam ser a ordem social tão vantajosa para a economia que deixaram algumas ideias eclesiásticas permanecer, por algum tempo, sem contestação. Assim, durante um extraordinário quarto de século, uma teocracia de clérigos pareceu dominar uma oligarquia de mercadores e homens de negócios.

O estudioso também destaca que, por intermédio do consistório ou presbitério, composto de cinco pastores e doze presbíteros leigos, todos eleitos pelo conselho, o clero exercia sua autoridade sobre a vida de Genebra. Como os pastores ocupavam o cargo durante todo o tempo de seu ministério e os presbíteros durante apenas um ano, o consistório, nas questões que não afetassem vitalmente os negócios, era governado por seus membros eclesiásticos. $\mathrm{O}$ consistório fazia pouca distinção entre reli- 
gião e moralidade. A conduta tinha de ser dirigida com o mesmo zelo que a crença, pois a boa conduta era o objetivo da verdadeira religião. A disciplina deveria ser a espinha dorsal da personalidade (DURANT, 1957).

Jogos, danças, canções indecentes, excessos e extravagâncias nas diversões e nos trajes foram proscritos. As cores das roupas foram reguladas por classes, assim como as atividades laborativas. Igualmente, foram estabelecidos os números de pratos permitidos numa refeição. Instituiu-se uma verdadeira disciplina dos corpos, num ordenamento em que cabia a toda pessoa aceitar o status quo social e executar resignadamente suas obrigações, sem invejar e sem se queixar (DURANT, 1957).

Enfim, o sagrado era domesticado por Calvino em Genebra como mãos de ferro. A selvageria representada pela hierofania da Reforma e suas ideias pioneiras de liberdade cristã e justificação pela fé eram por demais brutais para que não se preocupasse com a manutenção verticalizada da Igreja. O receio do sectarismo era presente em uma fé que, ela própria, já era sectária. O sagrado instituinte de uma contestação do monopólio eclesiástico, em toda sua fúria e desordem, precisava ser domado, dando lugar a um sagrado instituído, esquadrinhado, medido e, principalmente, manipulado pelas pessoas certas, pelos condutores dos cidadãos-fiéis.

Logo, a ideia de liberdade de crença e de consciência é naturalmente sufocada na experiência histórica de Calvino à frente da Igreja, contrariando o princípio da livre interpretação da Escritura, um dos pilares da própria eclosão da Reforma, justamente por ter a precisa noção de seu potencial inerentemente fragmentador da unidade doutrinária imprescindível ao crescimento da Igreja, o que já era possível de se experimentar naquele tempo, com a proliferação de seitas reformadas. $\mathrm{O}$ credo genebrino seria formulado pelo corpo eclesiástico e seria aplicado e exigido em toda Genebra.

Johnson reverbera essa ideia. Para ele, Calvino jamais defendeu ou propalou a liberdade de consciência cristã. Não seria possível a sociedade aperfeiçoada dos eleitos tolerar o dissonante, que certamente seria logo identificado como herege, excomungado, banido e, em alguns casos, executado (JOHNSON, 2001). A própria visão da pessoa de Deus passa por uma transformação, da Idade Média à Reforma. A ambivalente figura de 
Deus é igualmente relida. A face do bom Deus do Novo Testamento cede lugar à face de um Deus enérgico, típico do Antigo Testamento, numa representação muito mais consentânea com a necessidade de contenção e evocada pela disciplina (LE GOFF, 2007).

A tônica é, portanto, a da repressão, que passa a atingir todos os aspectos da vida do cidadão-fiel e que possui na moral seu mais precioso fundamento. Uma moral temporal e severa, intransigente e grave, que punia tanto o pecado sexual, quanto perseguia e tentava varrer a heresia intelectual, o que ficou explicitado no episódio da morte Miguel Serveto. Enfim, em Genebra eram perseguidas as impurezas, as danças, os adultérios e os desalinhados à doutrina da Igreja.

Verificado em suas nuances o esforço teórico e prático de Calvino para domesticar o sagrado selvagem, pode-se concluir que, a partir da experiência da Igreja de Genebra, Calvino estabelece uma instituição totalizante do sagrado. Da irrupção iconoclasta à estabilização institucional, Calvino codifica uma nova forma de experimentação do sagrado a ser apresentada aos cidadãos-fiéis. O sagrado em Genebra se revelava pela ordenação da vida em todos os seus aspectos. E, nesse ponto, a interface com o direito é algo imprescindível e inafastável. Ou seja: Calvino, num esforço de domesticação do sagrado selvagem, o qual não pode ser dissociado de uma redefinição do espaço político, acaba por desenvolver os elementos de uma nova ordem pública, sensivelmente influenciada pelo papel da Igreja e pragmaticamente informada por ferramentas jurídico-políticas.

\section{Conclusão}

A ciência das religiões difere-se da teologia porque aborda o fenômeno religioso sob um aspecto distinto, examinando-o não do ponto de vista da fé, mas da observação. O que está em análise não é a verdade do discurso religioso, mas a validade metodológica do argumento do pesquisador. A tarefa é a descrição e a análise do fenômeno religioso, com todas as suas características próprias e distintivas. 
O pesquisador tem o dever de compreender e tornar-se próximo da própria ideia que o fiel tem de sua religião. Esse seria o requisito de uma compreensão crítica e analítica da crença como objeto de estudo. E tal aproximação requer, antes de tudo, um profundo respeito para com todas as crenças em geral.

A partir dessa noção, o presente trabalho apresentou autores que viabilizam a tal reflexão, a fim de compreender o fenômeno por seus próprios aspectos religiosos e específicos, focando-se conceitualmente na especificidade do sagrado, na relação indissociável entre o sagrado e o profano e, ainda, nas dinâmicas de erupção do sagrado, em sua faceta selvagem, até sua institucionalização.

Ou seja, na definição dos marcos teóricos para a consecução do objetivo traçado, optou-se pela obra de autores ligados à ciência das religiões, de modo a buscar tanto os conceitos adequados a uma abordagem própria do fenômeno religioso intrinsecamente considerado, enfatizando suas especificidades a partir de um olhar endógeno dos postulados e experiências de fé que traduzem a crença analisada.

Nesse sentido, a pesquisa valeu-se tanto da dicotomia entre o sagrado e o profano, como da dialética do sagrado, de selvagem a domesticado, buscando, nesse processo, premissas para a verificação das possibilidades de análise do fenômeno jurídico a partir do prisma religioso.

A partir de tal esforço, toma-se o exemplo da teologia política de João Calvino. A consideração das manifestações do sagrado a partir das hierofanias da Reforma, bem como sua análise sob o viés da institucionalização desse novo arranjo do cristianismo como sistema de crenças, baseado na reflexão teórica e na experiência histórica, tiveram por objetivo, a partir de breves considerações sobre a experiência de Calvino em Genebra, sustentar a ideia segundo a qual a análise do fenômeno jurídico a partir de categorias do estudo das religiões pode se apresentar sobremaneira frutífera e enriquecedora para o estudo da história e da teoria do direito.

O mesmo pode se feito a partir de várias outras matrizes religiosas para além do cristianismo reformado. A religião romana, a religião islâmica e o próprio cristianismo medieval, dentre muitas outras experiências 
religiosas, certamente possuem estreitas interfaces com as formas jurídicas experimentadas na experiência histórica humana $\mathrm{O}$ presente trabalho, usando o exemplo de Calvino, é, pois, um movimento inicial na tentativa do estabelecimento de premissas metodológicas para a aproximação desses dois grandes campos do conhecimento.

\section{Referências}

AUGUSTO, Adailton Maciel. Aproximações entre Antônio Gouveia Mendonça e Roger Bastide. In: AUGUSTO, Adailton Maciel (Org.). Ainda sobre o sagrado selvagem: homenagem a Antônio Gouveia Mendonça. São Paulo: Paulinas, 2010. p. 25-48.

BASTIDE, Roger. O sagrado selvagem e outros ensaios. São Paulo: Companhia das Letras, 2006.

CALVINO, João. As institutas da religião cristã. Edição especial com notas para estudo e pesquisa. Tradução de Odayr Olivetti. São Paulo: Cultura Cristã, 2006. 4.v.

COELHO, Maria Efigênia Daltro. A importância da Ciência das Religiões como disciplina referencial no curso de Pedagogia. Domus on line, rev. Teor. pol. soc. Cidad., Salvador, v. 6-7, n. 1-12, p. 4858, jan.-dez. 2009-2010. Disponível em: <http://www.fbb.br/media/ Publica\%C3\%A7\%C3\%B5es/Domus\%20Vol\%206\%20e\%207/2\%20 Efigenia\%20domus\%20v\%206\%207\%202009\%202010.pdf $>$. Acesso em: 30 jul. 2014

CORRÊA, Caetano Dias. A reflexão teológico-política de João Calvino: institucionalização do sagrando e direito na aurora da modernidade. 2015. 159 p. Tese (Doutorado) - Universidade Federal de Santa Catarina, Centro de Ciências Jurídicas, Programa de PósGraduação em Direito, Florianópolis, 2015. Disponível em: <http://www. bu.ufsc.br/teses/PDPC1228-T.pdf>. Acesso em: 13 abr. 2017.

DURANT, Will. A Reforma. Tradução de Mamede de Souza Freitas. Rio de Janeiro: Record, [1957]. 
ELIADE, Mircea. O sagrado e o profano: a essência das religiões. São Paulo: Martins Fontes, 2005.

GRESCHAT, Hans-Jürgen. O que é ciência da religião? Trad. Frank Usarski. São Paulo: Ed. Paulinas, 2005.

HOPFL, Harro (Org.). Lutero e Calvino: sobre a autoridade secular. Tradução de Hélio de Marco Leite de Barros e Carlos Eduardo Silveira Matos. São Paulo: Martins Fontes, 2005.

JOHNSON, Paul. História do cristianismo. Tradução de Cristina de Assis Serra. Rio de Janeiro: Imago, 2001.

LE GOFF, Jacques. O Deus da Idade Média: conversas com Jean-Luc Pouthier. Tradução de Marcos de Castro. Rio de Janeiro: Civilização Brasileira, 2007.

MENDONÇA, Antônio Gouvêia. A experiência religiosa e a institucionalização da religião: Dossiê Religiões no Brasil. Estudos Avançados, São Paulo. IEA, v. 18, n. 52, setembro-dezembro, 2004. . A volta do sagrado selvagem: misticismo e êxtase no protestantismo do Brasil. In: AUGUSTO, Adailton, Maciel. Ainda sobre o sagrado selvagem: homenagem a Antônio Gouveia Mendonça. São Paulo: Paulinas, 2010. p. 477-496

OTTO, Rudolf. Lo santo: lo racional e lo irracional en la idea de Dios. Tradução de Fernando Vela. Madrid: Alianza, 1980.

PRODI. Paolo. Uma história da justiça. Tradução de Karina Janini. São Paulo: Martins Fontes, 2005.

SKINNER, Quentin. As fundações do pensamento político moderno. Tradução de Renato Janine Ribeiro e Laura T. Motta. São Paulo: Cia das Letras, 1996.

VILLEY, Michel. A formação do pensamento jurídico ocidental. Tradução de Cláusia Berliner. São Paulo: Martins Fontes, 2005. 
Caetano Dias Corrêa é doutor em Direito pela Universidade Federal de Santa Catarina, professor do curso de graduação em Direito na mesma instituição, professor dos cursos de pós-graduação em Direito da Católica de Santa Catarina e advogado.

E-mail: caetano@mh.adv.br.

Endereço profissional: Praça Pereira Oliveira, n. 64, $3^{\circ}$ Andar, Centro, Florianópolis, SC. - 88010-540. 
